\title{
Pendekatan Antropologis dalam Studi Islam
}

\author{
Asriana Harahap ${ }^{1}$, Mhd. Latip Kahpi ${ }^{2}$ \\ 1,2 Institut Agama Islam Negeri Padangsidimpuan, \\ e-mail: $\underline{1}$ asrianaharahap@iain-padangsidimpuan.ac.id, 2 latipkahpi@iain- \\ padangsidimpuan.ac.id
}

\begin{abstract}
Anthropology is the science of humans, especially about the origin, various colors of physical form, customs, and beliefs in the past. Epithemologically, anthropology studies various things about humans empirically in their relationship as biological beings and as social beings (in the sense of living in society). The method that is more appropriate with the anthropological approach is the holistic method. This means that seeing a social phenomenon must be examined in the context of the totality of the studied community culture. Meanwhile, the most appropriate data collection techniques are involved observation (observation) and in-depth interviews, that is, directly mingling in the community being studied.
\end{abstract}

Keywords: Approach, Anthropology, and Islamic Studies.

\begin{abstract}
Abstrak
Antoropologi merupakan cabang ilmu yang membahas tentang manusia dan kehidupannnya. Berbagai ragam kehidupanan manusia yang menyangkut bentuk fisik, adat istiadat dan kepercayaan manusia pada masa lampau. Secara teori antropologi adalah pelajaran berbagai hal tentang manusia secara observasi dalam kaitannya dengan makhluk biologi dan makhluk yang tidak bisa lepas dari orang lain. Cara yang lebih bagus dengan pendekatan antropogi adalah metode holistik. Dengan metode ini melihat sebuah fenomena yang sedang diteliti dengan cara yang lebih universal dan menyuluruh terhadap kebudayaan masyarakat yang dikaji. Penelitian ini menggunakan penelitian perpustakaan yaitu dengan menggunakan literatur kepustakan dari peneliti sebelumnya, dan memakai teknik analisis isi dan teknik komparatif konstan. Pendekatan sosiolgi dan antropologi dalam studi Islam merupakan hasil penelitian yang mengkaji kekhasan dari sifat manusia muslim di berbagai daerah di belajan bumi tentang bagaimana mereka hidup dengan menjalankan agama Islam.
\end{abstract}

Kata Kunci: Pendekatan, Antropologis, dan Studi Islam. 


\section{PENDAHULUAN}

Agama merupakan bentuk wahyu yang memeberikan petunjuk kepada umat manusia dalam menyelesaikan berbagai persoalan kehidupan manusia. Agama akan memberikan manusia cara pandang baru dalam kehiduapan sebagai jalan untuk masa kehidupan yang akan datang. Akan tetapi dewasa ini banya diantara manusia menjadikan agama sebagai sumber masalah dalam kehidupannya. (Harahap, 2018). Pada saat ini mayarakat justru dengan usaha menajga agama dari pengeroposan dan pencemaran dalam dataran praxis karena tidak semua ajaran-ajaran agama dilaksanakan dengan baik oleh pemeluknya atau dari pencemaran praktik-praktik dan pemikiran dari luar agama yang bercampur baur dengan agama. Fenomena yang terjadi akhir-akhir ini juga banyak kalangan yang menjadi sibuk membahas agama sehingga membuat mereka lupa akan esensi agama, banyak diantara kelompok yang menjadi perpecahan karena pemahaman tentng agama (Leni, 2018).

Hal yang paling utama dalam memaknai Islam ialah memkanai manusia itu sendiri. Pergumulan yang dirasakan manusia itu sendiri pada hakekatnya adalah keagamaan. Arti yang sebenarnya tentang keberagamaan manusia terdapat pada interpretasi dan pengalaman agama manusia itu sendiri. Sebab itu, antropologi sangat dibutuhkan untuk membahas Islam sebagai metode atau cara memaknai realitas manusia dan keberagaman agama (Bayani et al., 2021).

Berdasarkan uraian di atas maka penelitian ini akan mecoba membahas secara rinci tentang pendekatan antropologi dalam studi Islam.

\section{METODE PENELITIAN}

Jurnal ini dikaji berdasarkan penelitian dengan menggunakan Library Research (penelitian kepustakaan), penelitian yang menggunakan literatur yang berasal dari penelitian sebelumnya, dan memakai teknik analisis isi dan teknik analisis komparatif konstan. Teknik analisis isi dilakukan dengan melakukan kajian mendalam terhadap suatu informasi yang didapatkan secara tertulis baik di media massa maupun di media cetak. 
Analisis isi juga bisa dimaknai sebagai teknik penelitian untuk merujuk referensi yang bisa di adaptasi dengan mempedomani konteksnya. Berbada degan Analisis isi teknik Analisi Komparatif lebih melihat bagaimana suatu fenemona yang terjadi dabandingkan secara berkelanjutan dengan kejadian serupa saat penelitian sedang berlangsung. Tahapan yang dilakukan apada saat penerapan teknik ini adalah dengan membandingkan kejadian dalam setiap kategori, memadukan kategori beserta ciri-cirinya. Sehingga bisa didapatkan penelitia untuk ditelaah serta dianalisa beberapa konsep yang memiliki keterkaiatan dengan pokok bahasan yang disampaikan pada data penelitian ini sehingga informasi keilmuan bisa dijadikan untuk sumber primer serta sekunder.

\section{HASIL DAN PEMBAHASAN}

Antropoli berasal dari kata Antropos dan Logos. Antropos merupakan manusia sedangkan Logos adalah Ilmu. Dengan kata lain atropologi merupakan cabang keilmuan yang membahas tentang manusia di mana membahas tentang asal-usul, aneka warna bentuk fisik, adat istiadat, dan kepercayaan pada masa lampau (Potabuga, 2020). Secara epistemologis antropolog mempelajari tentang berbagai hal yang berkaitan dengan kehiduapan manusia secara empirik dan sebagai makshluk sosisal hubungan dengan masyarakat. Manusia secara biologis memiliki perbedaan warna kulit, bentuk tubuh sifat dan fisik lainnya. Manusia terlahir sudah memilikikelompok dan tumbuh dalam kehidupan masyarakat dengan kebudayaan tertentu. (Abdullah, 2007).

Antropologi dibagi dua yaitu, antropologi fisik dan antropologi budaya, termasuk etimologi dan ilmu bahasa (Nata, 2002).

Kebudayaan di antara manusia masing-masing memiliki perbedaan yang secara harus diakui keberadaannya, maka kajian antropoligi tidak hanya melihat aspek kebudayaan sebagai objek kajiannya tapi termasuk keberagamaan karena memiliki keterkaitan dengan pola kehidupan manusia (Tama et al., 2016)

Ada beberapa cabang Ilmu Antropologi: 1) antropologi Lingisutik 2) antropologi budaya 3) antropologi arkeologi 4) antropologi agama. 
Dinatara konsep yang paling penting dalam kajian antropologi adalah kajian holisme, pandangan ini berpendapat kegiatan sosial harus dikaji dan diteliti dalam konsteks dan secara esensial dipandang sebagai suatu kajian yang memiliki keterikatan dengan yang lain dalam masyarakat yang sedang diteliti. antropolog juga harus memberikan pandangan terhadap situasi praktek keagamaan, pertanian, magik, politik dan kekeluargan secara bersamaan (Muhaimin, 2012). Oleh karena itu agama mislanya tidak dapat dipandang sebagai sesuatu yang otonom yang tidak memeliki pengarus dengan praktik lainnya. Para antroplog pula melihat peran agama dalam memproduksi problem-problem dan keteganganketegangan, misalnya menganalisis peran agama dalam memelihara struktur kekuatan yang ada atau yang mendorong kohesi sosial (Khoiri, 2002).

Southwold menyatakan ada 12 karakteristik, di antaranya adalah sebagai berikut: Concern pada sesuatu yang ilahiah dan hubungan manusia dengan Nya. Di mana ada sebuah kitab suci atau tradisi oral yang mulai. Adanya pendekatan (Nabi) atau spesialis elit keagamaan. Berkaitan dengan suatu komunitas moral. Ada kaitannya dengan kelompok etnis atau kelompok yang sama (Khoiri, 2002).

Diantara pendapat yang dianggap memiliki ketepatan di antaranya dengan menggunakan pendekatan holistik. Pendapat ini menekankan pentingnya pemahaman secara komperhensif terhadap penomena dalam masyarakat yang menjadi bahan kajian (Nasution, 2007).

Brian Moris memberikan pandangan kajian agama secara antropologi dapat dilakukan dengan menjadikan agama sebagai krangka sosial empiris, kemudia menjadikan agama sebagai bahagian dari kehidupan manusia yang dapat dikaji dan diteliti (Baharun, 2011).

Dalam kajian antropologi kehidupan umat manusia di dunia ini pasti ditemukan adanya pluralitas atau keanekaragaman, kemajemukan. Pluralitas dalam kehidupan bermasyakat menjadi warna tersendiri untuk saling melengkapi dan saling membutuhkan.

Antropologi memiliki tujuan untuk memahami objek kajian secara totalitas, dari masa kuno hingga masa modren saat ini., melihat manusia 
dalam bingkai eksistensi biologi dan kultural. Antropologi berusaha untuk membuka tabir proses perubahan yang terjadi dalam kehidupana manusia baik yang berkaitan dengan budaya dan agama secara universal (Koentjaraningrat, 2000).

Metode empirik adalah memperhatikan segala sesuatu yang dipikirkan, diyakini, dirasakan, dan dikerjakan oleh masyarakat yang bersangkutan. Dengan menggunakan metode yang bagus untuk ini adalah dengna partisipan serta observation (Harahap, 2019).

Pada hakikatnya, setiap norma yang turun dari Tuhan yang terdapat di dalam kitab suci yang mulia tidak dapat diteliti secara ilmiah. Serta norma dan kepercayaan tersebut telah dimiliki oleh manusia (baik manusia itu para ulama atau para pemuka agama, maupun orang awam pengikut biasa) ia dapat menjadi objek kajian antropologi (Agus, 2006).

Kajian antropoligi dalam agama adalah bukan melihat fenomena ajaran yang datang dari Tuhan, melainkan melihat fenomena beragamanya manusia. Sebagai suatu disiplin ilmu sosial, antropologi tidak memperdebatkan salah benarnya suatu agama dan segenap perangkatanya, seperti kepercayaan, ritual, dan kepercayan terhadap sesuatu yang dianggap sakral (Potabuga, 2020). Setiap norma, nilai, keyakinan yang ada dalam pikiran, hati, dan perasaan manusia memiliki kebudayaan. Perilakunya juga bisa dilihat dalam kehidupan nyata dan hasil material dari kreasi, pikiran, dan perasaan manusia (Potabuga, 2020).

Pada prinsipnya terdapat kaitannya degan Islam sebagai gejala antropologi, banyak kajian yang mendiskusikannnya. Pembahasan ini telah dibahas pada bab sebelumnya, dan diantaranya dalam bentuk apa yang disebut gejala agama dan keagamaan. Terdapat beberapa gejala yang dapat dilakukan penelitian terhadap kajian antropoligi studi Islam diantaranya, naskah-naskah yang menjadi sumber ajaran agama, pengikut, pemimpin atau tokoh agama, yang berkaitana dengan pemahaman, sikap, perilaku, pandangan, dan penghayatan. Ritul ibadah seperti sholat, puasa, haji, perkawinan, peringatan kelahiaran Nabi, atau bisa jadi juga lembaga-lembaga yang ada dalam agama seperti lembaga waqaf, zakat, masjid. Kemudian bisa juga dilihat berdasarkan orgaisasi 
keagamaan yang ada seperti Muhammadiyah, NU, Al Waslyah dan sebagainya.

Kajian antropologi dalam studi Islam dilakukan dengan upaya untuk memahami gejala-gejala keagamaan dengan melihat berbagai praktik keagamaan yang tumbuh dan berkembang di tengah-tengah masyarakat. Tindakan ini dilakukan sebagai ihkhtiar untuk melihat dan memperkuat posisi agama dalam kehidupan manusia (Baharun, 2011).

Tahapan dalam pemahaman Islam tidak akan lengkap tanpa melihat secara holistik antara budaya dan manusia. Kehidupan beragama yang sesungguhnya adalah realitas kehidupan manusia yang mengejewantahkan dunia nayata. Maka bisa dipastikan makna hakik dari keberagamaan adalah terletak pada interpretasi dan pengalaman agama. Oleh karenanya ilmu antropolig diperlukan untuk memahami gejalagejala yang terjadi dalam kehiduapan beragama manusia.

Dalam kajian antropologi modren ada yang dikenal denan istilah holisme, pandangan ini menyatakan dalam kajian antropologi harus melihat praktik sosial secara esensial sebagai suatu gejala yang berkaitan dengan masyarakan yang diteliti. Antropolog tidak bisa menapikan kehidupan lain masyarakat yang diteliti dengan hanya menlihat aspek keagamaan. Singkatnya melihat fenomena keagamaan yang terjadi di masyarakat memiliki keterkaitan dengan kehidupan lai, sperti pertani, keluarga ekonomi, bahkan kehidupan politiknya (Huda, 2016).

Pendekatan antropologi dan studi agama membuahkan antropologi agama yang dapat diakatakan sebagian dari antropoli budaya, bukan antropologi sosial. Antropologi agama sebagai bagian memiliki sistetematika keilmuan yang kuat.

Sejalan dengan pendapat antropologi itu, sehingga dalam berbagai data antropologi agama dapat ditemukan adanya kolerasi pasif antara keyakinan agama dengan kondisi ekonomi dan politik. Golongan masyarakat yang kurang mampu dan golongan miskin pada umumnya lebih tertarik kepada gerakan-gerakan keagamaan yang bersifat mesianis, yang menjanjikan perubahan tatanan sosial kemasyarakatan. Sedangkan golongan orang kaya lebih cenderung untuk mempertahankan tatanan 
masyarakat yang sudah mapan secara ekonomi lantaran tatanan itu menguntungkan pihaknya. Melalui pendekatan antropologi dapat dilihat bahwa agama ternyata berkorelasi dengan kerja dan perkembangan ekonomi suatu masyarakat. Dalam hubungan ini seseorang ingin mengubah pandangan dan sikap etos kerja maka dapat dilakukan dengan cara mengubah pandangan keagamaannya (Abdullah, 2006).

Melalui pendekatan antropologis terlihat dengan jelas hubungan agama dengan berbagai masalah kehidupan manusia. Pendekatan antropologis seperti itu diperlukan adanya, sebab masalah agama hanya bisa dijelaskan dengan tuntas melalui pendekatan antropologi. Artinya manusia dakam memahami ajaran agama, dapat dijelaskan melalui bantuan ilmu antropologi dengan cabang-cabangnya (Nata, 2002).

Agama sebagai objek kajian antropologi dapat dilihat dalam dua hal. Pertama antropologi merupakan bahagian dari kajian kebudayaan yang menjadi penting memiliki sasaran kajian tersendiri yang disebut dengan antropologi agama. Kedua, semua cabang keilmuan antropologi merupakan kajian yang miliki hubungan dengan rumpun kajian kebudayaan sehingga salah satu pendekatan yang dapat dilakukan adalah pendekatan kebuayaan (Huda, 2016).

Nurcholis Majid memberikan penjelasan antara hubungan agama dan budaya. Dalam pandangannya agama dan budaya merupakan dua istilah yang memiliki perbedaan tapi tidak bisa dipisahkan. Agama memliki nilai yang mutlak, yang tidak berubah karena dipengaruhi ruang dan waktu, sedangkan budaya akan memiliki terus perubahan sesuai kebutuhan serta tuntan zaman (Hakim, 2009).

Terdapat kelebihan dan kekurangan dalam pendekatan antropologi dalam studi Islam, sebagai berikut: Kelebihan pendekatan antropologi memiliki corak yang deskriptif dengan pematangan langsung, ssehingga peneliti mengetahui bagaimana sebenarnya praktik keberagamaan (local practis) praktik nayata yang terjadi di suatu tempat. Antropologi akan mencari keterkaitan antara berbagai domain kehidupan secara lebih utuh dan melakukan perbandingan dari berbagai tradisi. Dengan antropologi kita dapat memahami berbagai corak dan perilaku manusia berdasarkan 
keberagamaan yang dilakukannya. Kekurangannya antropologi tidak membahas fungsi agama bagi manusia, tetapi membahas isi unsur-unsur pemebentuk dalam agama dan itu berkaitan dengan manusia dan kebudayaannya. Dalam kehidupan terjadi perubahan budaya yang sangat cepat sehigga kita harus teliti dan update dalam mengamatinya, sehingga dalam praktiknya jika tidak cermat maka akan susah membedakan antara agama dan budaya.

Kebudayaan dapat dijadikan sebagai pendekatan dalam memahami Islam, terutama mengenai ajaran Islam dalam tataran empiris, sebagai ajaran agama Islam yang tampil dalam bentuk formal dan terjadi masyarakat. Agama dalam bentuk demikian berkaitan dengan bentuk kebudayaan yang berkembang di masyarakat atau tempat agama itu berkembang. Misalnya kita dapat menjumpai kebudayaan berpakaian, bergaul, bermasyarakat, dan sebagainya. Dalam produk kebudayaan tersebut unsur agama ikut berintegrasi. Seperti bentuk model berbusana bagi wanita dan jilbab (Ghazali, 2015).

Contoh pendekatan antropologi dalam studi Islam yaitu tentang jual beli. Dalam konsep Islam Allah mengajarkan tentang hallanya sebuah jual beli dan tidak membenarkan tindakan riba. (Q.S al-baqarah ayat 275) yang menjadi dasar dalam Islam adalah tentang bahwa tindakan jual beli yang sah dilakukan berarti itu menjadi halal, dan perbuatan yang mengakibatkan kerugian disalah satu pihak karena riba maka itu merupakan sesuatu yang haram. Maka selanjutnya aspek yang berkaitan dengan jual beli merupakan hal yang menjadi budaya seperti adanya penjual, pembeli serta adanya barang yang akan diperjualbelikan. Maka hal-hal yang berkaitan dengan wilyah aspek keagamaan menjadi wilayah yang bisa didiskusikan termasuk bagaimana persyaratan menjadi penjual, pembeli yang sah, bagaimana barang yang boleh diperjual belikan serta bagaimana cara sehingga ada kesepakatan yang menjadi akad dalam aktivitas juall beli (Hakim, 20015).

Jika dilihat secara historis diatara pendekatan ulama dalam penyebaran Islam dilakukan dengan pendekatan antropologis yang memadukan antara budaya dan agama sebagai corak untuk persuasi 
dalam menyampaikan risalah kebenaran kepada umat. Perumaan yang lain dalam kajian antropologis dalam Islam adalah adanya berbagai upacara yang diyakini untuk mendapatkan kemuliaan seperti, mangupa, pesta perkawinan, upacara lahiran ini merupakan aktivitas keagamaan yang berkaitan dalam kajian antropologis Islam. Karena banyak kalangan umat Islam melakukan hal semacam itu (Hakim, 20015).

\section{PENUTUP}

Antropologi merupakan cabang keilmuan yang membahas tentang manusia khususnya membahas tentang awal mula manusia itu sendiri, aneka warna bentuk fisik manusia, kebiasaan manusia, serta keyakinan manusia pada masa lalu. Sedangkan menurut istilah antropologi merupakan satu disiplin ilmu yang mendiskusikan tentang hal yang berkaitan dengan manusia secara empirik, baik sebagai makhluk biologis atau merupakan makhluk sosial. Terdapat bebrapa karakterisktik yang menjadi dasar dalam melakukan kajian antropologi, diantaranya dengan melakukan kajian secara holistik sesuatu yang berkaitan anatara manusia dengan sang khaliq-Nya.

kajian antropoligi studi Islam diantaranya, naskah-naskah yang menjadi sumber ajaran agama, pengikut, pemimpin atau tokoh agama, yang berkaitana dengan pemahaman, sikap, perilaku, pandangan, dan penghayatan. Ritul ibadah seperti sholat, puasa, haji, perkawinan, peringatan kelahiaran Nabi, atau bisa jadi juga lembaga-lembaga yang ada dalam agama seperti lembaga waqaf, zakat, masjid. Kemudian bisa juga dilihat berdasarkan orgaisasi keagamaan yang ada seperti Muhammadiyah, NU, Al Waslyah dan sebagainya.

Pendekatan sosiologi dan antropoigi dalam kajian studi Islam adalah sebagai upaya untuk melihat berbagai keunikan dan dimensi kehidupan manusia dalam berbagai tempat dalam menjalankan kehidupan beragamanya sebagai umat Islam. Pendekatan ini memfokuskan kajiannya untuk memahami agama dengan melihat praktik sosial yang terjadi secara empirik dalam kehidupan nyata manusia. 
Pendekatan ini memiliki kelebihan dalam kajian studi Islam dengan ilmu antropologi kita dapat milahat asal-usul agama, dan dengan begitu akan muncul pemahaman terkait pola pikir dan perilaku penganutnya. Berdasarkan kajian yang dilakukan secara antropologi kita juga bisa melitahat keterkaitan anatara agama dan manusia terutama zaman dahulu. Sementara itu, disiplin ilmu ini juga memiliki kekurangan dalam kehidupan manusia terjadi banyak transformasi dalam berbagai hal yang mempengaruhi kehidupan manusia, sehingga peneliti harus cermat dan cepar dalam melakukan pengamatan. Karena jika tidak akan banyak perubahan yang terjadi sehingga sangat sulit membedakan antara agama dan budaya, ditambah lagi jika dalam hal pengamatan terjadi kesalahan dan kekeliruan maka akan terjadi kesalahan dalam pengambilan kesimpulan. 


\section{DAFTAR PUSTAKA}

Abdullah Yatimin. (2006). Studi Islam Kontemporer. Jakarta: Amzah.

Agus Bustanuddin. (2006). Agama dalam Kehidupan Manusia: Pengantar Antropologi Agama. Jakarta: Rajawali.

Baharun Hasan. (2011). Metodologi Studi Islam: Percikan Pemikian Tokoh dalam Membumikan Agama. Yogyakarta: Ar Ruzz Media.

Bayani, D., Di, I., \& Bunayya, S. (2021). Integrasi Struktur dan Fungsi Bagian Tumbuhan. 1(1), 19-31.

Hakim Atang Abd, dkk. (2015). Metodologi Studi Islam, Bandung: Remaja Rosdakarya.

Harahap, A. (2018). Education Thought of Ibnu Miskawaih. Sunan Kalijaga International Journal on Islamic Educational Research, 1(1), 1-14. https://doi.org/10.14421/skijier.2017.2017.11-01

Harahap, A. (2019). Gender Typing (Pada Anak Usia Sekolah Dasar). AlMuaddib: Jurnal Ilmu-Ilmu Sosial $\mathcal{E}$ Keislaman, 4(1), 1. https://doi.org/10.31604/muaddib.v1i1.781

Huda, M. D. (2016). Pendekatan Antropologis dalam Studi Islam. Didaktika Religia, 4(2), 139-162. https://doi.org/10.30762/didaktika.v4.i2.p139162.2016

Khoiri Imam. (2002). Aneka Pendekatan Studi Agama. Yogyakarta: LkiS.

Koentjaraningrat. (2000). Pengantar Ilmu Antropologi. Jakarta: Binacipta.

Leni, N. (2018). Peran Antroplogi Bagi Studi Islam. Analisis: Jurnal Studi Keislaman, 18(2), 233-252. https://doi.org/10.24042/ajsk.v18i2.4138

Maliki Zainuddin. (2010). Sosiologi Pendidikan. Yogyakarta: UGM Press.

Muhaimin. (2012). Studi Islam: dalam Ragam Dimensi dan Pendekatan. Jakarta: Kencana. 
60 | TAZKIR: Jurnal Penelitian Ilmu-ilmu Sosial dan Keislaman

Vol. 07 No. 1 Juni 2021

Nasution Khoiruddin. (2007). Pengantar Studi Islam. Yogyakarta: Academia dan Tazzafa.

Nata Abudin. (2002). Metodologi Studi Islam. Jakarta: Raja Grafindo Persada.

Potabuga, Y. F. (2020). Pendekatan Antropologi Dalam Studi Islam. Transformatif, 4(1), 19-30. https://doi.org/10.23971/tf.v4i1.1807

Rosyidi. (1974). Kuliah Agama di Perguruan Tinggi. Jakarta: Bulan Bintang.

Tama, T. D., Adisasmita, A. C., \& Burhan, E. (2016). Indeks Massa Tubuh dan Waktu Terjadinya Konversi Sputum pada Pasien Tuberkulosis Paru BTA Positif di RSUP Persahabatan Tahun 2012. Jurnal Epidemiologi Kesehatan Indonesia, 1(1), 1-8. https://doi.org/10.7454/epidkes.v1i1.1309

Tim Penyusun. (2005). Pengantar Studi Islam. Yogyakarta: Pokja Akademik UIN Sunan Kalijaga. 